\section{Field Survey and Fungicide Screening of Fungal Pathogens of Rambutan (Nephelium lappaceum) Fruit Rot in Hawaii}

\author{
Lisa Keith ${ }^{1}$ and Tracie Matsumoto \\ Tropical Plant Genetic Resource and Disease Research Unit, Pacific Basin \\ Agricultural Research Center, USDA-ARS, 64 Nowelo Street, Hilo, HI 96720
}

Kate Nishijima and Marisa Wall

Tropical Crop and Commodity Protection Research Unit, Pacific Basin Agricultural Research Center, USDA-ARS, Hilo, HI 96720

\author{
Mike Nagao \\ University of Hawaii at Manoa, Hilo, HI 96720
}

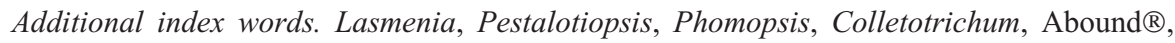
Trilogy®

\begin{abstract}
Rambutan (Nephelium lappaceum Linn.) is a tropical fruit in Hawaii that has increased in value in the niche market of exotic fruits. The primary limitation to preharvest and postharvest quality is the occurrence of fungal diseases of the fruit. A survey of rambutan disease was conducted at orchards $9.7 \mathrm{~km}$ south and $29.0 \mathrm{~km}$ north of Hilo, HI, to determine the main fungal pathogens affecting preharvest fruit quality. Pericarp of rambutan fruit revealed brown to black lesions that progressed to blackening and drying of the fruit with some fruits becoming totally mummified. Four fungi consistently isolated from symptomatic fruit included Lasmenia, Pestalotiopsis, Phomopsis, and Colletotrichum spp. Over the 2-year sampling period, disease incidence from more than 300 fruits sampled was $\mathbf{8 4 . 6 \%}$. Nine rambutan cultivars were evaluated for disease incidence under field conditions. Disease incidence was greater than $90 \%$ for 'Sitangku' and 'R167' but less than $60 \%$ for 'Chompoo'. Twelve fungal isolates from infected fruit were selected for further characterization (six Lasmenia isolates and two isolates each of Pestalotiopsis, Phomopsis, and Colletotrichum). Morphology, colony characteristics, and pathogenicity of the isolates were examined. The optimum growth temperature for all fungal isolates ranged between 22 and $28^{\circ} \mathrm{C}$. Molecular methods were used to confirm the identity of the fungi. The fungal isolates were evaluated for in vitro baseline sensitivities for mycelial growth for fungicides registered for use in Hawaii (Abound $^{\circledR}$ and Trilogy ${ }^{\circledR}$ ). Abound ${ }^{\circledR}$ was more effective at inhibiting fungal growth than was Trilogy ${ }^{\circledR}$; however, efficacy appeared to be influenced by fungal genera. Inhibition of fungal growth by Abound ${ }^{\circledR}$ ranged from a $76 \%$ reduction for Lasmenia to a $23 \%$ reduction for Phomopsis isolates.
\end{abstract}

Rambutan is a tropical tree in the Sapindaceae that produces delicious edible fruits, is native to Malaysia and Indonesia, and is commonly cultivated throughout Southeast Asia (Morton, 1987). Rambutan flourishes from sea level to $600 \mathrm{~m}$ in tropical, humid regions having well-distributed rainfall (Morton, 1987). Depending on location, rambutan can produce up to two crops a year

Received for publication 23 Sept. 2010. Accepted for publication 3 Mar. 2011.

We thank Maile Skomp Velasquez and Lionel Sugiyama for technical assistance.

Mention of trademark, proprietary product, or vendor does not constitute a guarantee or warranty of the product by the U.S. Dept. of Agriculture and does not imply its approval to the exclusion of other products or vendors that also may be suitable.

${ }^{1}$ To whom reprint requests should be addressed; e-mail Lisa.Keith@ars.usda.gov.
1983; Visarathanonth and Ilag, 1987). Lasmenia and Gliocephalotrichum have been previously reported as fungal pathogens on rambutan in Hawaii (Nishijima et al., 2002). Dolabra nepheliae causes a stem canker disease on rambutan; although it is classified as a minor disease by the Food and Agriculture Organization, it may have the potential to cause damage to fruit production (Rossman et al., 2007). Information on the identity and biology of the main fungal species that cause disease and understanding the disease epidemiology and potential for cross-infection are important so that effective control measures can be developed and implemented (Hopkins and McQuilken, 2000).

Superior fruit quality is necessary for Hawaii's specialty fruit industry to have a competitive advantage. To develop an integrated system of preharvest and postharvest practices that enable specialty tropical fruit growers to manage diseases, improve fruit quality, and extend shelf life, the economically important fungal pathogens must be identified, etiology information must be understood, and control measures must be developed. The objectives of this study were to: 1) identify the causal agent(s) of commonly observed symptoms of fruit rot of rambutan in Hawaii and establish pathogenicity by fulfilling Koch's postulates; 2) compare fungal isolates by studying pathogenicity, morphological, cultural, and molecular characteristics; 3) examine the effect of temperature on growth of the pathogens; and 4) determine the in vitro efficacy of fungicides currently registered for use on rambutan in Hawaii.

\section{Materials and Methods}

Field observations and symptoms. During 2006 to 2007, rambutan trees with fruit were examined at the Tropical Plant Genetic Resource and Disease Research Unit orchard located at the University of Hawaii, Waiakea Agricultural Experiment Station, Hilo, HI, and at a nearby commercial farm in Paukaa, HI. The sites are $9.7 \mathrm{~km}$ south and $29.0 \mathrm{~km}$ north of Hilo, respectively, with an elevation ranging from 74 to $227 \mathrm{~m}$. Maximum and minimum mean temperatures are 28 and $16{ }^{\circ} \mathrm{C}$, respectively. Annual rainfall averages from 3632 to $4445 \mathrm{~mm}$ and is most abundant during October to February. The soil consists of an extremely stony Papai muck with organic soils formed over mostly fragmental a'a lava. Digital photographs of leaf and fruit symptoms were recorded using a Nikon Coolpix 995 model digital camera (Melville, NY).

Collection of isolates. Naturally infected, symptomatic fruit of nine rambutan cultivars were collected from fields in Hilo and the surrounding area. All fungi were grown on potato dextrose agar (PDA) (Difco Laboratories, Detroit, MI) at $24{ }^{\circ} \mathrm{C}$ under continuous fluorescent illumination, and single spore cultures were derived from each isolate and stored at room temperature $\left(20^{\circ} \mathrm{C}\right)$ in sterile distilled water (SDW).

Initial identification and cultural characteristics. The fungal isolates derived from 
single spores were maintained on PDA. Cultures were incubated at $24{ }^{\circ} \mathrm{C}$ in continuous light and cultural morphology was examined after 7 to $30 \mathrm{~d}$. Colony color was defined according to Raynor (1970). For Pestalotiopsis, isolates were identified by comparing morphological and cultural characteristics (i.e., size of the conidia, color and length of median cells, length and number of apical appendages, and length of basal appendage) to those described in Guba's (1961) monograph of Monochaetia and Pestalotia. Lasmenia, Phomopsis, and Colletotrichum spp. were identified based on morphological and physiological characteristics and on literature reports (Farungsang et al., 1994b; Nishijima et al., 2002).

Temperature effects on mycelial growth. Five replicate, $10-\mathrm{cm}$ diameter petri dishes containing PDA $(25 \mathrm{~mL})$ were inoculated centrally with an agar disc ( $5 \mathrm{~mm}$ diameter) of a subset of fungal isolates cut from the edge of an actively growing culture on PDA. The effect of temperature on colony diameter was determined after 4 and $7 \mathrm{~d}$ at 10, 15, 20, $26,28,32$, and $37{ }^{\circ} \mathrm{C}$ under continuous fluorescent illumination. All temperature experiments were conducted twice.

Pathogenicity tests. Pathogenicity tests consisted of inoculations of harvested rambutan fruit (cultivar R134). Before inoculation, fruit were surface-disinfested by immersion in $10 \%$ bleach solution $(0.5 \%$ sodium hypochlorite) for $2 \mathrm{~min}$, rinsed in SDW, air-dried in a laminar flow hood, and placed in plastic chambers containing moistened paper towels. Fruit were wounded with a sterile cork borer and inoculated with mycelial discs (3 $\mathrm{mm}$ diameter) of fungal isolates grown for $5 \mathrm{~d}$ at $28^{\circ} \mathrm{C}$. Controls were inoculated with PDA discs only. Fruit were observed for symptoms over a period of $7 \mathrm{~d}$. To fulfill Koch's postulates, diseased tissue was placed on water agar and PDA and observed for culture characteristics similar to that of the inoculum strains used for inoculations. Experiments were repeated at least twice with similar results.

Molecular identification. Total genomic DNA was extracted from fungal isolates following the protocol described in Keith et al. (2006). Polymerase chain reactions (PCRs) to amplify ITS Regions 1 and 2 were largely based on Caetano-Annolles et al. (2001) and White et al. (1990). PCR products were cloned (TA cloning kit; Invitrogen Co., San Diego, CA) and plasmid DNA for sequencing was prepared (Qiagen plasmid miniprep kit, Chatsworth, CA). DNA sequencing was performed at Eurofins MWG Operon (Huntsville, AL). Similarity searches of the GenBank database were performed with BLAST (Altschul et al., 1990).

Determination of sensitivity of fungal isolates to fungicides. Efficacy of two fungicides registered for use on rambutan in Hawaii to inhibit fungal growth was determined using amended media. For all studies, commercial formulations were used: azoxystrobin, Abound ${ }^{\circledR}$ 2.08 EC (Syngenta Crop Protection, Greensboro, NC) and clarified hydrophobic extract of Neem Oil, Trilogy® (Certis USA, Columbia, MO). These fungicides were diluted in sterile water and added to molten PDA to obtain final concentrations as recommended by the manufacturer. Sensitivities of fungal isolates to Abound ${ }^{\circledR}$ and
Trilogy ${ }^{\circledR}$ were tested using radial growth (RG) assays. Each isolate (Table 1) was cultured on PDA at $24{ }^{\circ} \mathrm{C}$ for $7 \mathrm{~d}$. Fivemillimeter-diameter mycelial plugs were cut from the margins of colonies and transferred onto three PDA dishes amended with each

Table 1. Fungal isolates used in this study, their cultivar hosts, and sample origin.

\begin{tabular}{llll}
\hline Isolate & \multicolumn{1}{c}{ Name } & \multicolumn{1}{c}{ Cultivar } & \multicolumn{1}{c}{ Plant part } \\
\hline 20-3B & Lasmenia sp. & Daun Hijau & Mature rambutan fruit, base of spintern \\
9-5A & Lasmenia sp. & Sileng Keng & Mature rambutan fruit, spintern \\
10-5 & Lasmenia sp. & Sileng Keng & Mature rambutan fruit, spintern \\
25-2 & Lasmenia sp. & Sitangku & Mature rambutan fruit, rind \\
$9-2$ & Lasmenia sp. & Sileng Keng & Mature rambutan fruit, spintern \\
$9-5 \mathrm{~B}$ & Lasmenia sp. & Sileng Keng & Mature rambutan fruit, spintern \\
15-5 R12T12 & Pestalotiopsis sp. & R167 & Mature rambutan fruit, rind \\
15-2 & Pestalotiopsis sp. & R167 & Mature rambutan fruit, rind \\
21-4B & Colletotrichum sp. & Gula Batu & Mature rambutan fruit, base of spintern \\
25-4 & Colletotrichum sp. & Sitangku & Mature rambutan fruit, spintern \\
7-2B & Phomopsis sp. & Chompoo & Mature rambutan fruit, rind \\
15-4 & Phomopsis sp. & R167 & Mature rambutan fruit, spintern \\
\hline
\end{tabular}

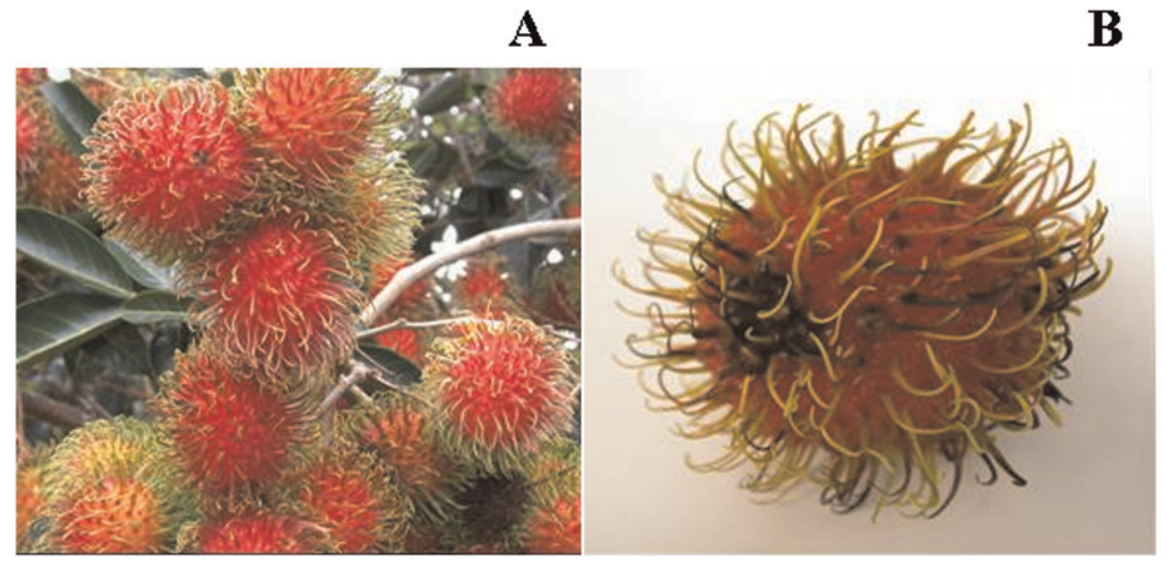

Fig. 1. Symptoms of fruit disease of rambutan seen in the field. (A) Discrete dark brown lesions on the fruit surface and dark brown to black, coalescing lesions giving rise to dried and cracked appearance (cultivar Jitlee). (B) Mature cultivar Binjai fruit with dark brown lesions on rind and spinterns.

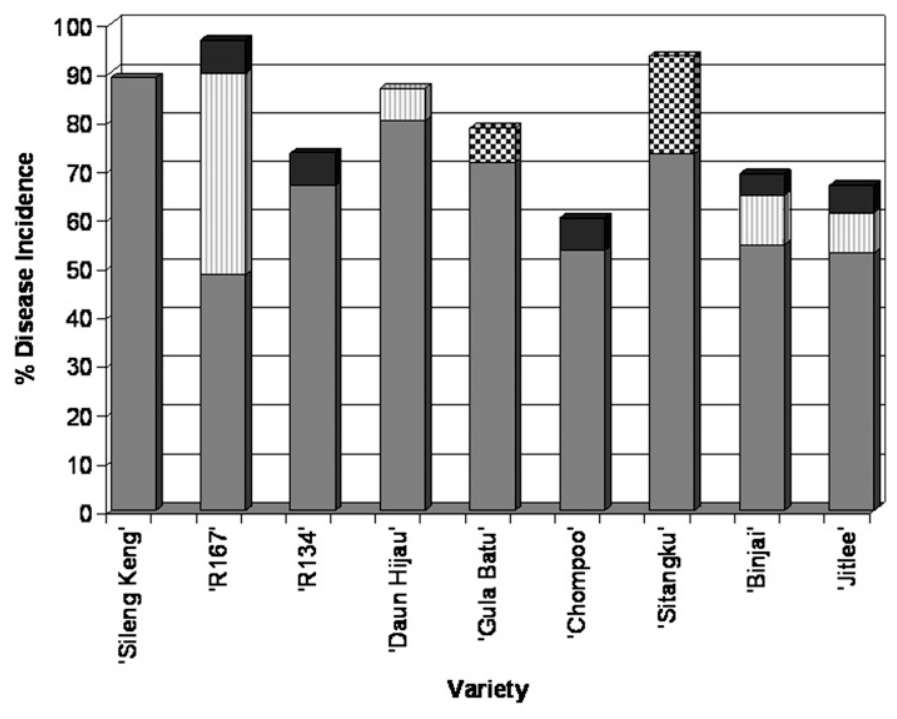

$\square$ Lasmenia $\square$ Pestalotiopsis 1 Phomopsis Q Colletotrichum

Fig. 2. Disease incidence of the four main fungal pathogens (Lasmenia, Pestalotiopsis, Phomopsis, and Colletotrichum spp.) found on several rambutan fruit cultivars grown at orchards in Waiakea and Paukaa. 
concentration of fungicide (Trilogy $®=1 / 3 \times$ or $3,380 \mathrm{ppm}, 1 \times$ or $10,140 \mathrm{ppm}$, and $3 \times$ or 30,420 ppm; Abound ${ }^{\circledR}=118.3 \mathrm{~mL} / 378.5 \mathrm{~L}$ or $75 \mathrm{ppm}, 183.4 \mathrm{~mL} / 378.5 \mathrm{~L}$ or $116 \mathrm{ppm}$, and $455.4 \mathrm{~mL} / 378.5 \mathrm{~L}$ or $289 \mathrm{ppm})$. Plates were maintained at $24{ }^{\circ} \mathrm{C}$ with continuous lighting. Colony diameter (RG) was measured across two axes, averaged, and the diameter of the mycelial plug subtracted from the average after 4 and $7 \mathrm{~d}$. Growth inhibition in response to each fungicide at varying concentrations was compared with the control plates (PDA only). Each experiment was conducted twice.

\section{Results}

Field observations and symptoms. A preharvest fungal disease survey on rambutan was conducted at the Waiakea Agricultural Experiment Station and at a local farm. Disease symptoms were visible on leaves during non-fruiting seasons and on the exocarp of mature and immature fruits (pinhead size), which progressed as fruits got larger. Typical symptoms included tiny brown to black spots on the spinterns or on the surface of the fruit (Fig. 1A-B). The spots darkened in color and became crusty in appearance. The tiny spots progressively expanded to discrete, circular, dark brown to black spots, which dried out and developed into cracks in the pericarp.

Isolation and identification. Isolates were obtained over a 2-year period from more than 300 immature and mature fruit samples exhibiting disease symptoms. The single-spore fungal cultures were maintained on PDA and stored in SDW for additional studies. The study identified Lasmenia, Colletotrichum, Pestalotiopsis, and Phomopsis as the predominant pathogens in the Waiakea fields. The disease incidence varied among the nine cultivars of rambutan ('Sileng Keng', 'R167', 'R134', 'Daun Hijau', 'Gula Batu', 'Chompoo', 'Sitangku', 'Binjai', and 'Jitlee') (Fig. 2). Lasmenia was the most frequently isolated pathogen from lesions. Disease incidence for Lasmenia was greater than $88 \%$ for 'Sileng Keng' but less than $48 \%$ for 'R167'. Disease incidence for Pestalotiopsis was greater than $41 \%$ for 'R 167 ' but less than $7 \%$ on 'Daun Hijau'. Disease incidence for Phomopsis was relatively low for 'R167', 'R134', and 'Chompoo' (less than 7\%). Results were similar for Colletotrichum on 'Sitangku'.

'Jitlee', 'Binjai', and 'R167' rambutan trees were surveyed for incidence and etiology of fruit rot infection at a commercial grower's farm in Paukaa, and results were similar to those found at the Waiakea fields. Fruit rot incidence was greatest for Lasmenia at $64.3 \%$ of all fungi identified. 'Binjai' had less incidence to fungal infection compared with the other two cultivars. Phomopsis and Pestalotiopsis were also isolated along with Gliocephalotrichum and Lasiodiplodia, although incidence was less than $7 \%$.

A second etiological survey of cultivars Binjai, Jitlee, and R167 was conducted in Paukaa, HI, and 72 isolations were obtained from 24 fruits. Several fungal strains were isolated and included Lasmenia (48\%), Pestalotiopsis (8\%), Gliocephalotrichum (14.2\%), and Phomopsis (1.4\%). A cultivar effect was seen with certain pathogens. 'Binjai', 'Jitlee', and 'R167' were equally infected with Lasmenia (55\% incidence). However, 'Binjai' and 'Jitlee' had lower incidences of Pestalotiopsis than R167 (9\% compared with 41\%, respectively).

Temperature effects. Temperature had an effect on the colony diameter of the 12 isolates examined (Fig. 3). When grown on PDA, most isolates grew at a temperature range of 10 to $32{ }^{\circ} \mathrm{C}$ with optimum growth between 20 and $28{ }^{\circ} \mathrm{C}$. Within $7 \mathrm{~d}$, the majority of the diameter of mycelial growth of the isolates measured $\approx 80 \mathrm{~mm}$, the diameter of the PDA plate. The temperature range for growth of five of the six Lasmenia analyzed

$\mathbf{A}$

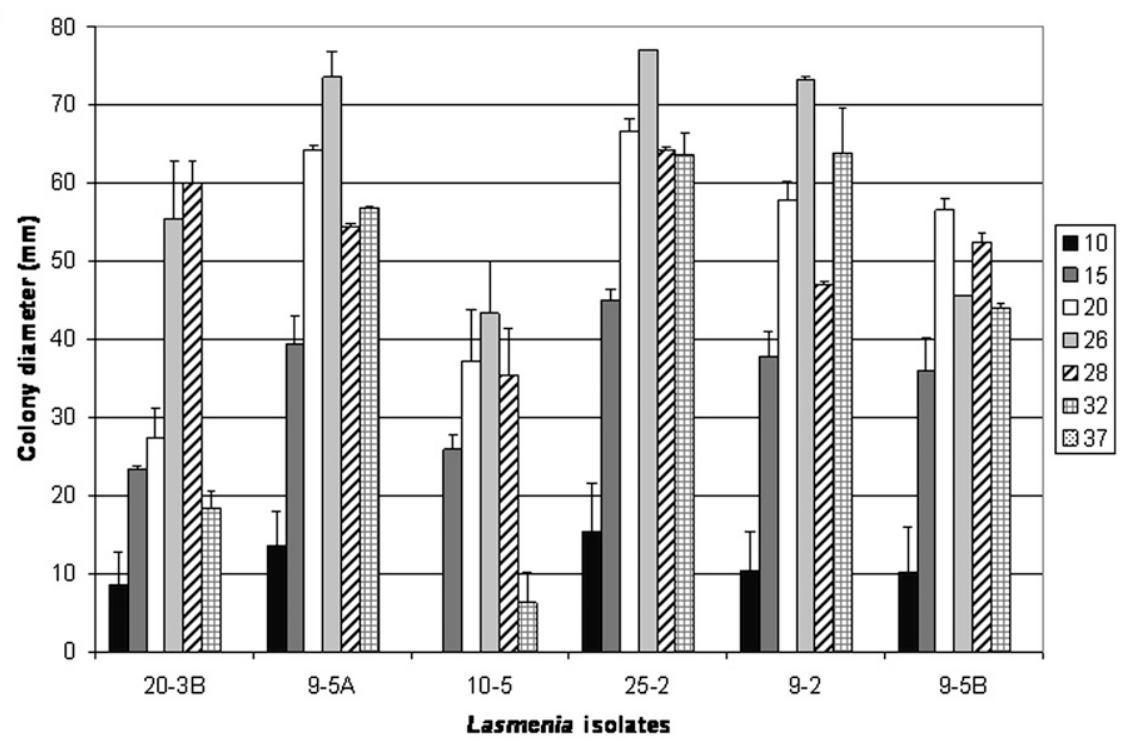

B

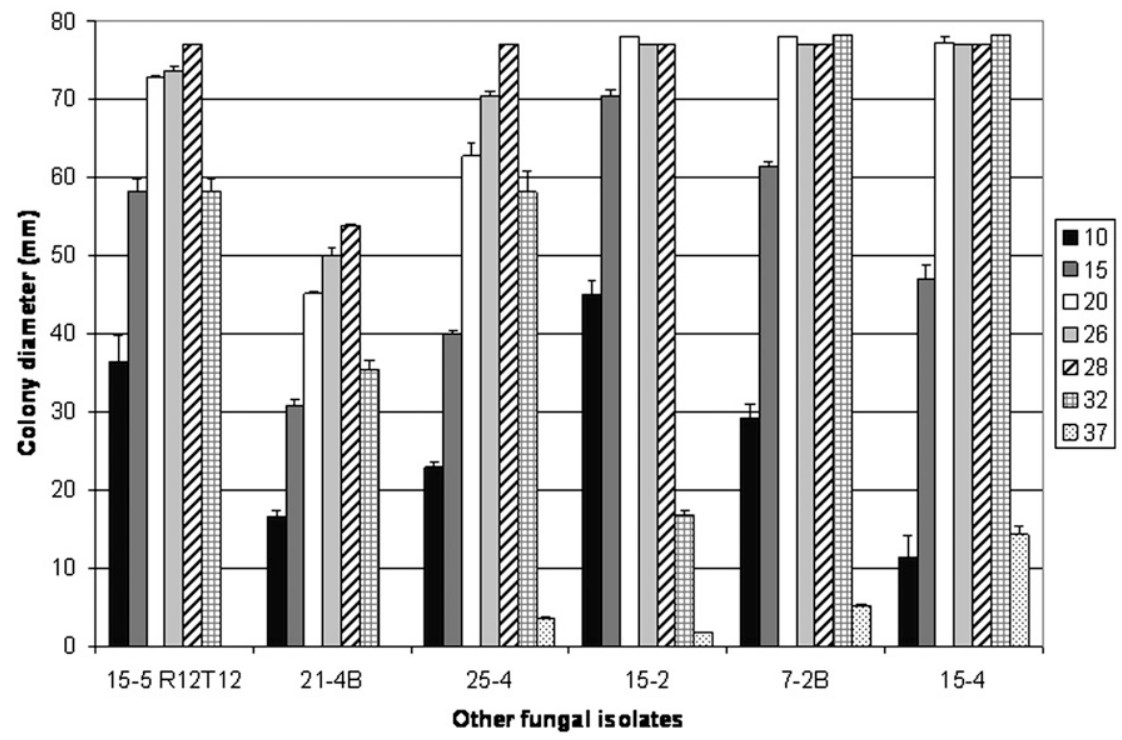

Fig. 3. Influence of temperature $\left(10,15,20,26,28,32\right.$, and $\left.37^{\circ} \mathrm{C}\right)$ on mycelial growth of (A) Lasmenia isolates and (B) Pestalotiopsis (15-5 R12T12 and 15-2), Phomopsis (7-2B and 15-4), and Colletotrichum (21-4B and 25-4) isolates from diseased rambutan fruit. Growth after $7 \mathrm{~d}$ on potato dextrose agar. Each bar represents mean $\pm \operatorname{SEM}(n=5)$. 
were not observed on control fruit inoculated with agar media. Wounding was necessary for symptom development for Pestalotiopsis. Wounding was not necessary for the three other genera; however, it decreased the time necessary for onset of infection. The fungi were reisolated from the lesions of the diseased fruit and were identical to the original isolates, thus confirming Koch's postulates.

Determination of sensitivity of fungal isolates to fungicides. In vitro fungicide resistance screening tests were conducted with the 12 Lasmenia, Phomopsis, Pestalotiopsis, and Colletotrichum isolates. Trilogy ${ }^{\circledR}$ was used at concentrations equal to $1 / 3 \times, 1 \times$, and $3 \times$ the recommended field concentration for tropical fruits (where $1 \times=1 \%$ or 10,140 ppm) (Fig. 4). Fungi exhibited mild susceptibility to Trilogy ${ }^{\circledR}$ with only a $57 \%$ reduction in growth rate observed for Lasmenia and a 17\% reduction for Phomopsis, Pestalotiopsis, and Colletotrichum depending on concentration, indicating that Trilogy ${ }^{\circledR}$ may be ineffective for control in the field. In vitro fungicide screening results for Abound ${ }^{\circledR}$ showed more promise (Fig. 5). Lasmenia growth rates were reduced by more than $76 \%$ using recommended rates for tropical fruits (6.2 to $15.4 \mathrm{fl}$. oz. product/A). The growth of the other strains (Pestalotiopsis and Colletotrichum) was reduced $46 \%$. However, Abound $\AA$ only resulted in a $23 \%$ reduction in growth for Phomopsis, indicating that not all fungi are inhibited to the same degree.

\section{Discussion}

Four pathogens, Lasmenia, Pestalotiopsis, Phomopsis, and Colletotrichum spp., were identified as the main fungal pathogens causing fruit rot on Hawaii-grown rambutan. Field symptoms were similar for all four genera (tiny brown to black spots on the spinterns or on the rind of the fruit, which expanded over time resulting in a dried out or crusty-looking appearance), which makes fungal identification extremely important for disease control. The fungi were isolated from lesions on fruit at all levels of maturity. In the Philippines, postharvest losses in rambutan resulting from disease have been reported to be $\approx 30 \%$ to $40 \%$ (Visarathanonth and Ilag, 1987). In a study by O'Hare et al. (1994), all organisms isolated from diseased rambutan were fungal; Pestalotiopsis sp., Colletotrichum sp., and Phomopsis sp. were detected on all cultivars analyzed, including 'R162', 'Jit Lee', and 'R156'. They have been previously identified as rambutan pathogens (Farungsang et al., 1991; Visarathanonth and Ilag, 1987) and are similar to the results of our study. In Thailand, Pestalotiopsis fruit rot is one of the most serious postharvest diseases of rambutan (Sangchote et al., 1998). Pestalotiopsis also causes gray spot disease on rambutan in China (He et al., 2010). For most rambutan fruit rots, fungicide applications before and after harvest help control the pathogens (Farungsang et al., 1994b; Saenyoung

$\mathbf{A}$

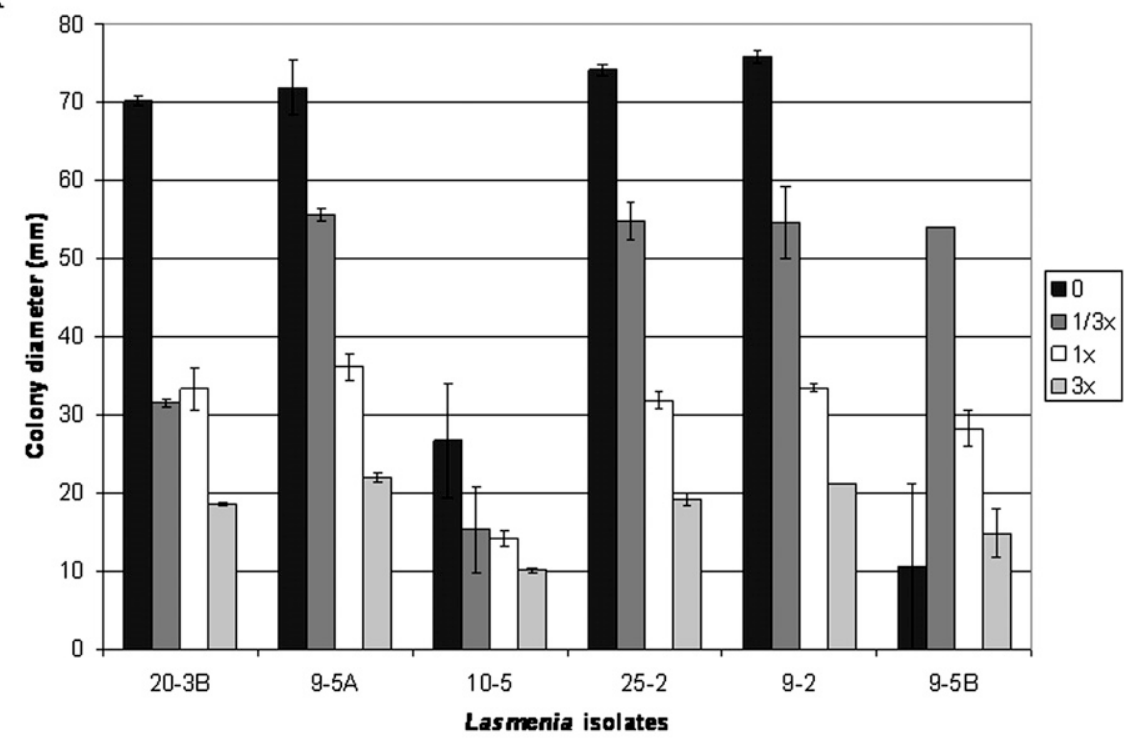

B

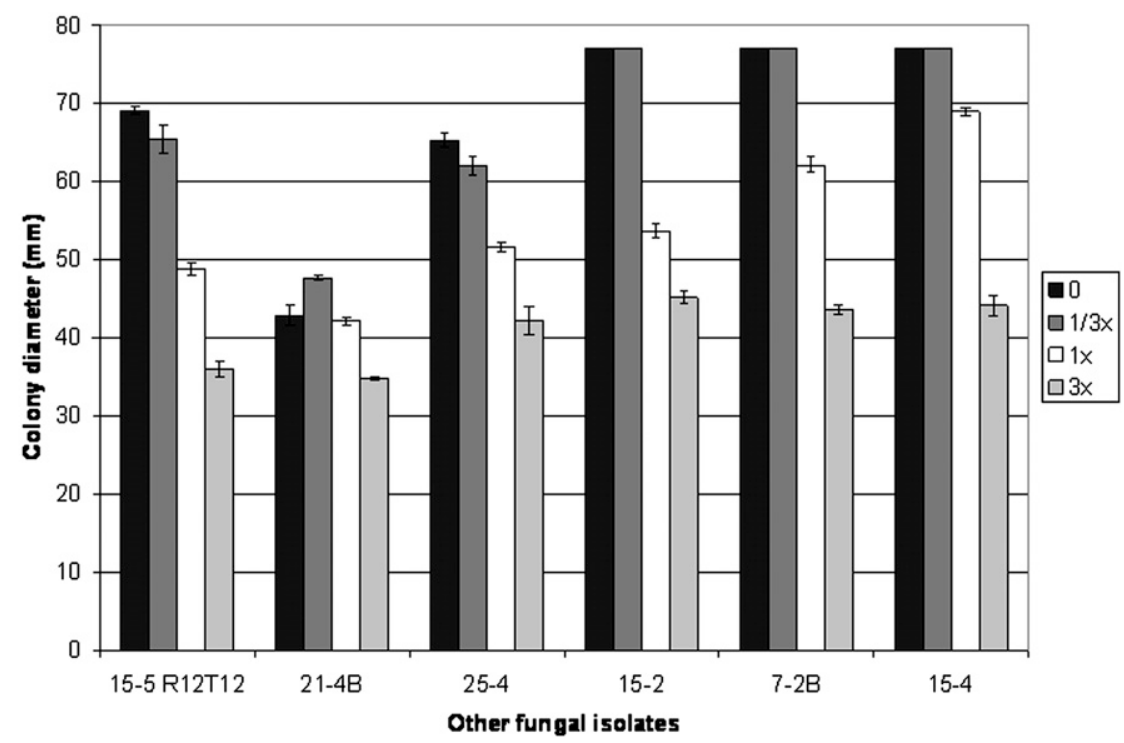

Fig. 4. Influence of Trilogy ${ }^{\circledR}$ treatment on in vitro mycelial growth of (A) Lasmenia isolates and (B) Pestalotiopsis (15-5 R12T12 and 15-2), Phomopsis (7-2B and 15-4), and Colletotrichum (21-4B and 25-4) isolates from diseased rambutan fruit. Growth after $7 \mathrm{~d}$ at $24{ }^{\circ} \mathrm{C}$ on potato dextrose agar (PDA) only or PDA amended with different concentrations of Trilogy ${ }^{\circledR}(1 / 3 \times=3,380 \mathrm{ppm}, 1 \times=10,140 \mathrm{ppm}$, and $3 \times=30,420 \mathrm{ppm})$. Each bar represents mean \pm SEM $(\mathrm{n}=3)$.

and Visarathanonth, 1985). Abeyesekere et al. (1997) also found that fungicide applications could control the three major postharvest diseases of rambutan in Sri Lanka.

All the pathogens grew well at temperatures commonly found in Hawaii orchards. Sangchote et al. (1992) found that storage temperatures influenced the spectrum of fungi associated with postharvest rambutan decay. Koch's postulates were confirmed, and we found that wounding before inoculation was necessary for disease development for Pestalotiopsis sp. According to Visarathanonth and Ilag (1987), wounding was necessary for rapid penetration and severe infection of rambutan and explained why mechanically injured fruit were prone to fruit rot. In our study, wounding was not necessary to establish infection by Lasmenia, Phomopsis, and
Colletotrichum spp. suggesting that virulence is greater in these fungi and proper field management practices are crucial for disease control. Although the in vitro studies may not directly simulate the conditions of the natural environment, the results provide insight to the likely behavior and growth of the pathogens in nature. The in vitro growth studies may also indicate that disease development could be delayed during postharvest storage by the inhibition or slowing of fungal growth by low temperature (Johnson and Cooke, 1990).

Anthracnose, caused by Colletotrichum gloeosporioides, is a serious disease of rambutan that affects leaves, flowers, and harvested fruit in high rainfall growing regions including the Philippines, Sri Lanka, and Thailand; fruit infection occurs in the field 
A

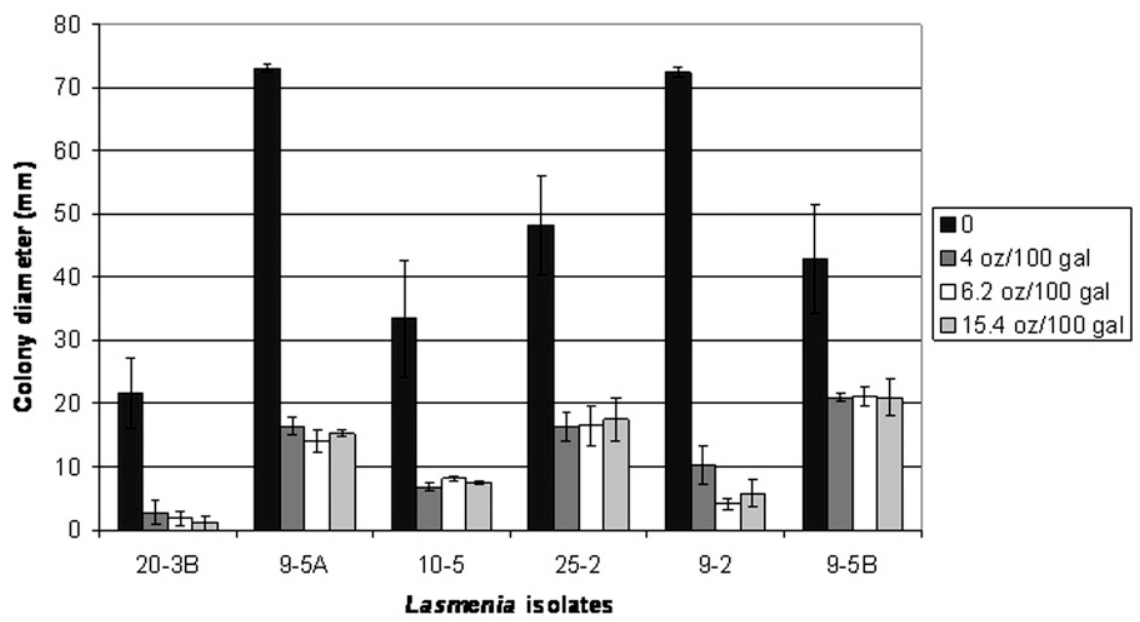

B

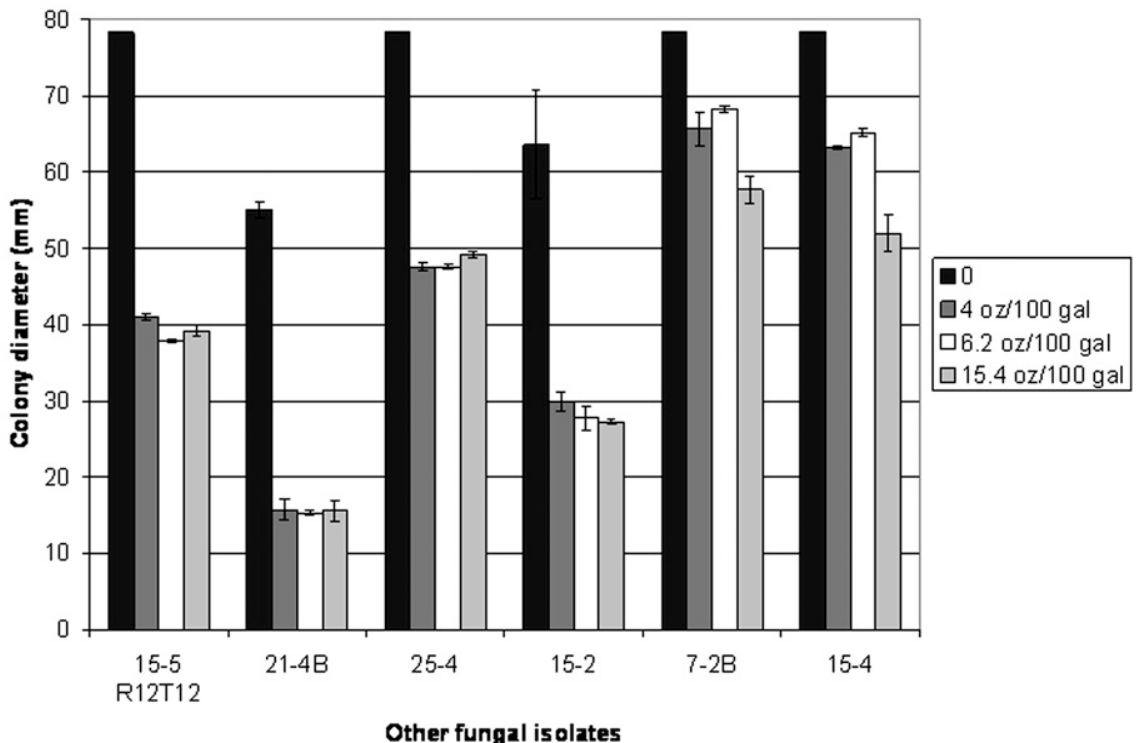

Fig. 5. Influence of Abound ${ }^{\circledR}$ treatment on in vitro mycelial growth of (A) Lasmenia isolates and (B) Pestalotiopsis (15-5 R12T12 and 15-2), Phomopsis (7-2B and 15-4), and Colletotrichum (21-4B and 25-4) isolates from diseased Hawaiian rambutan fruit. Growth after $7 \mathrm{~d} 24^{\circ} \mathrm{C}$ on potato dextrose agar (PDA) only or PDA amended with different concentrations of Abound ${ }^{\circledR}(4 \mathrm{oz} / 100 \mathrm{gal}=75 \mathrm{ppm}, 6.2$ $\mathrm{oz} / 100 \mathrm{gal}=116 \mathrm{ppm}$, and $15.4 \mathrm{oz} / 100 \mathrm{gal}=289 \mathrm{ppm})$. Each bar represents mean $\pm \mathrm{SEM}(\mathrm{n}=3)$.

but usually remains quiescent until fruit ripens or is harvested (Farungsang et al., 1991; Sivakumar, 1996; Visarathanonth and Ilag, 1987). Anthracnose is best controlled by a combination of sanitation; field applications of fungicides, including mancozeb, zineb, and/or benomyl from flowering to harvest; and optimum postharvest storage (Tindall, 1994; Visarathanonth and Ilag, 1987). In the study by Sivakumar et al. (1999), accumulation of leaf litter led to significantly higher levels of brown spot disease, indicating that the presence of leaf litter was a constant source of fungal inoculum, especially during wet weather when rain splash can carry the inoculum onto the leaf and fruit surface. Factors that favor fungal infection of rambutan include: inadequate field spraying to reduce latent infection and surface contamination, injuries that occur during harvesting, and high humidity and temperature during packaging, fungicide. Field studies are necessary to determine if additional fungicides currently registered for use in Hawaii can help control pre- and/or postharvest fruit rot caused by the four fungal pathogens identified in this study.

\section{Literature Cited}

Abeyesekere, M., N.A.N.A. Nettikumara, R.S. Wilson Wijeratnam, D. Sivakumar, and P. Kurukuladithya. 1997. Studies on preharvest treatments for control of postharvest pathogens of rambutans. Proc. Australian Postharvest Horticultural Conf., Sydney, Australia. p. 152-154.

Altschul, S.F., W. Gish, W. Miller, E.W. Myers, and D.J. Lipman. 1990. Basic local alignment search tool. J. Mol. Biol. 215:403-410.

Caetano-Annolles, G., R.N. Trigiano, and M.T. Windham. 2001. Patterns of evolution in Discula fungi and the origin of dogwood anthracnose in North America, studied using arbitrarily amplified and ribosomal DNA. Curr. Genet. 39:346-354

Chayasombat, A. and S. Sangchote. 1983. Fruit rot of rambutan caused by Botryodiplodia theobromae Pat. Proc. of the 21st National Conference on Agricultural and Biological Sciences. Kasetsart University, Bangkok, Thailand. p. 408-415.

Farungsang, U., N. Farungsang, and S. Sangchote. 1991. Postharvest diseases of rambutan during storage. 8th Australian Plant Pathological Society Conference (Abstract). p. 114.

Farungsang, U., N. Farungsang, and S. Sangchote. 1994a. Preliminary investigation of microorganisms antagonistic to Colletotrichum gloeosporioides obtained from rambutan. ACIAR Proc. 50:375-377.

Farungsang, U., S. Sangchote, and N. Farungsang. 1994b. Rambutan postharvest diseases in Thailand. ACIAR Proc. 58:51-59.

Griffee, P.J. 1973. Resistance to benomyl and related fungicides in Colletotrichum musae. Trans. Br. Mycol. Soc. 60:433-439.

Guba, E.F. 1961. Monograph of Pestalotia and Monochaetia. Harvard University Press, Cambridge, MA.

He, C.P., X.-L. Zheng, R. Li, W.-H. Wu, X.-M. Yu, X.-Y. Ke, and F.-C. Zheng. 2010. Identification and biological characters of rambutan gray spot disease. CNKI Journal. J. Fruit Sci. 2 Mar. 2011. $<$ http://en.cnki.com.cn/Journal_en/D-D048-GSKK2010-02.htm>.

Hopkins, K.E. and M.P. McQuilken. 2000. Characteristics of Pestalotiopsis associated with hardy ornamental plants in the UK. Eur. J. Plant Pathol. 106:77-85.

Johnson, G. and T. Cooke. 1990. Stop the rot: Disease control after harvest. QDPI technical feature. Queensland Fruit and Vegetable News 25:15-17.

Keith, L.M., M.E. Velasquez, and F.T. Zee. 2006. Identification and characterization of Pestalotiopsis spp. causing scab disease of guava, Psidium guajava, in Hawaii. Plant Dis. 90: $16-23$.

Laksmi, L.D.S., P.F. Lam, D.B. Mondoza, Jr., S. Kosiyachinda, and P.C. Leong. 1987. Status of the rambutan industry in ASEAN, p. 1-8. In: Lam, P.F. and S. Kosiyachinda (eds.). Rambutan: Fruit development, postharvest physiology and marketing in ASEAN. ASEAN Food Handling Bureau, Kuala Lumpur, Malaysia.

Morton, J. 1987. Rambutan, p. 262-265. In: Morton, J.F. (ed.). Fruits of warm climates. Creative Resources Systems, Inc., Miami, FL. 
National Agricultural Statistics Service-USDA, Hawaii Field Office. 2009. Hawaii Tropical Specialty Fruits. Annual Report, released 18 Sept. 2009. NASS, USDA, and Hawaii Department of Agriculture, Agricultural Development Div., Honolulu, HI. 21 Sept. 2009. <http://www.nass.usda. gov/Statistics_by_State/Hawaii/Publications/ Fruits_and_Nuts/tropfrt.pdf>.

Nishijima, K.A., P.A. Follett, B.C. Bushe, and M.A. Nagao. 2002. First report of Lasmenia sp. and two species of Gliocephalotrichum on rambutan in Hawaii. Plant Dis. 86:71.

Ogawa, J.M., B.T. Menji, C.R. Heaton, J. Petie, and R.M. Sonada. 1983. Methods for detecting and monitoring the resistance of plant pathogens to chemicals, p. 177-192. In: Georghiou, G.C. and T. Saito (eds.). Pest resistance to pesticides. Plenum Press, New York, NY.

O'Hare, T.J., A. Prasad, and A.W. Cooke. 1994. Low temperature and controlled atmosphere storage of rambutan. Postharvest Biol. Technol. 4:147-157.

Raynor, R.W. 1970. A mycological colour chart. Commonwealth Mycological Institute, Kew, UK.
Rossman, A.Y., R. Goenaga, and L. Keith. 2007. First report of Dolabra nepheliae on rambutan and litchi in Hawaii and Puerto Rico. Plant Dis. 91:1685.

Saenyoung, S. and N. Visarathanonth. 1985. Effects of four fungicides for control of fruit rots of rambutan. Proc. of the 23rd National Conference on Agriculture and Biological Sciences (Poster session), Kasetsart University, Bangkok, Thailand. p. 371-379.

Sangchote, S., U. Farungsang, and N. Farungsang. 1992. Rambutan diseases. In: ACIAR Project 8844, Wkshp Postharv. Hand. Trop. Fruit, July 1992, Bangkok, Thailand, p. 17.

Sangchote, S., U. Farungsang, and N. Farungsang. 1998. Pre- and postharvest infection of rambutan by pathogens and effects of postharvest treatments. In: Coates, L.M., P.J. Hofman, and G.I. Johnson (eds.). Disease control and storage life extension in fruit. Proc. of an International Workshop held at Chiang Mai, Thailand, 22-23 May 1997. ACIAR Proc. 81:87-91.
Sivakumar, D. 1996. Developing technologies to minimize postharvest losses of rambutan. MPhil thesis, Univ. of Colombo, Sri Lanka.

Sivakumar, D., R.S. Wilson Wijeratnam, and R.L.C Wijesundera. 1999. Field sanitation and the occurrence of brown spot disease of rambutan (Nephelium lappaceum) fruits. J. Natn. Sci. Foundation Sri Lanka 27:93-97.

Tindall, H.D. 1994. Rambutan cultivation. In: FAO Plant Production and Protection Paper No. 121. p. 135-141.

Visarathanonth, N. and L.L. Ilag. 1987. Postharvest diseases of rambutan, p. 51-57. In: Lam, P.F. and S. Kosiyachinda (eds.). Rambutan: Fruit development, postharvest physiology and marketing in ASEAN. ASEAN Food Handling Bureau, Kuala Lumpur, Malaysia.

White, T.J., T. Bruns, S. Lee, and J. Taylor. 1990. Amplification and direct sequencing of fungal ribosomal DNA genes for phylogenetics, p. 315321. In: Innis, M.A., J. Gelfand, J. Sninky, and T.J. White (eds.). PCR protocols: A guide to methods and applications. Academic Press, San Diego, CA. 